\title{
The effect of budgetary participation on managerial performance: internal control and organizational commitments as intervening variables
}

\author{
Hendrik Sastrawan ${ }^{1}$, Fajar Gustiawaty Dewi ${ }^{2}$, Yuliansyah Yuliansyah ${ }^{3}$ \\ Faculty of Economics and Business, University of Lampung, Bandar Lampung, Indonesia ${ }^{1,2,3}$ \\ hendriksastrawan.liaw@gmail.com
}

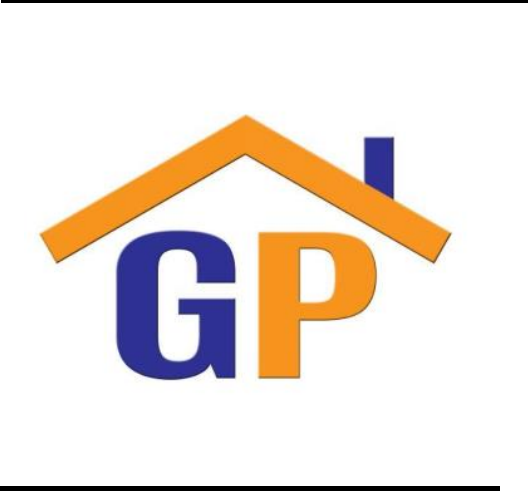

Article History

Received on: 15 December 2019

Revised on: 2 March 2020

Accepted on: 2 March 2020

\begin{abstract}
Purpose: This study aims to examine the effect of budgetary participation on managerial performance with internal control and organizational commitment as an intervening variable, in a stateowned plantation company, namely PT Perkebunan Nusantara VII.
\end{abstract}

Research methodology: Using a questionnaire survey study for 100 respondents involved in the budgeting process at PT Perkebunan Nusantara VII, this study analyzed the data using SEM PLS, SmartPLS 3.2 software.

Results: The results show that budgetary participation has a positive effect on managerial performance directly. Meanwhile, internal control is an intervening variable into the relationship between budgeting participation and managerial performance. On the contrary, organizational commitment is not proven as an intervening variable into the relationship between budgeting participation and managerial performance.

Limitations: This study contributes to the management accounting literature and provides an overview of the effectiveness of regulations, policies and work programs that have been made by companies in improving managerial performance, particularly those relating to budgeting, internal control, and organizational commitment.

Contribution: The study attempts to offer new insights on the influence of budgeting participation, internal control and organizational commitment, and other variables in improving managerial performance in state-owned plantation companies.

Keywords: Budgeting participation, Managerial performance, Internal control, Organizational commitment

How to cite: Sastrawan, H., Dewi, F. G., Yuliansyah, Y. (2019). The effect of budgetary participation on managerial performance: internal control and organizational commitments as intervening variables. Journal of Social, Humanity, and Education, 1(1), 3951.

\section{Introduction}

Plantations commodities have credible characteristics andhave been traded globally. Price and commodity productivity and operational costs are the main factors to determine companies'performance both in private plantation companies and state-owned plantation companies (PTPN). Private plantation companies are more dynamic in improving their performance while state- 
owned plantation companies such as PTPN do not yet show improvements in their performance significantly.

PTPN VII has experienced a less healthy condition since the last 10 years due to an unbalanced cash flow because of thee falling of commodity prices in global markets, bad climate, and plant rejuvenation. PTPN VII performance has been measured in terms of commodity productivityand profit-loss in several periods that have not been reached according to a predetermined budget.

Target standards or accurate budgetary are needed to achieve better managerial performance. Budgeting needs the participation of each section or department involved in it so that the budget is right on target and its purpose. This needs to be done due to their deep understanding related to budgetary participation (Selvina \& Yuliansyah, 2015). According to Brownell (1982), budgetary participation is a process in which subordinates or staff are given the opportunity by superiors to get involved and have an influence on the process budget setting. Both superiors and subordinates involved in the participatory budgeting process will better understand, accept decisions, and feel bound by decisions(Yahya et al., 2008).

Organizational commitment is encouragement from within individuals to do something to achieve goals and success of the company and prioritize the interests of the company over own interests. Budgetary support from staff can increase the closeness of relations between employees with organizational commitment so that it will affect performance (Arsalan et al., 2018). For instance, Yuliansyah \& Khan (2017), Yuliansyah, et al. (2018), and Yuliansyah, et al. (2019) find that with proper trust, appreciation, and encouragement by top managements, employees' participation in budgeting will give maximum advantage to organization.

Employees will be of disadvantages if performance targets are not achieved, such as a promotion delay and bonus cancelation. This encourages employees to conduct monitoring and evaluation of budget execution through internal control activities.

Several studies on the relationship between budgetary participation and managerial performance show inconsistent results (see for example Arsalan et al., 2018; Rosman et al., 2016; Setiadi and Yuyetta, 2013; Cheng, 2012; Haryanti and Othman, 2012; Lau and Tan, 2012; Yahya et al., 2008; Eker, 2007; Supriyono, 2004; Poerwati, 2002; Naori and Parker, 1998), therefore, there is a need to further test the consistency of those findings if applied to environmental conditions which are different, especially in state-owned plantation companies.

\section{Literature review and hypothesis development}

Grand theory that can support the independent variables in this study is contingency theory. According to Aulad et al (2018), contingency theory is a theory used to find out and analyze designs in management accounting systems that provide precise information to explain variations in an organizational structure. Contingency approach allows other variables to be moderating or intervening factors that influence budgetary participation on managerial performance (Poerwati, 2002). Moderating factors are factors or variables that influence the relationship between two variables, while intervening factors are factors or variables that are influenced by one variable and affect other variables.

A budget is a formal and systematic statement regarding a detailed plan of action by management, arranged based on a number of assumptions of activities to be carried out, measured in monetary units and other units, and used as a guide for the implementation of activities in a certain time, usually one year (Arsalan et al., 2018). Meanwhile, budget participation is defined as a process in which managers are involved and have an influence on determining their budgets. Staff is expected to provide relevant work information and share iinformation externally related to environmental uncertainty and information asymmetry so that budgetary participation can encourage staff to design budget-based performance which is more efficient (Shields, 1998). Furthermore, Cheng (2012) provides evidence showing that there is a role in budgetary participation in which employees gather, exchange, and disseminate information relevant to the work tohelp corporate decision making, which enables managerial performance goals to be achieved.

Based on classical management, managerial performance is the managers' ability to do some management functions including planning, investigation, coordination, evaluation, supervision, staff selection, negotiation, and participation (Mahoney et al., 1965 in Indarto and Ayu, 2011). In 
management accounting approach, performance refers to both quality and quantity generated or services provided by someone who does the work. This is to measure the effectively and efficiently about the managers who have worked to achieve organizational goals.

Internal control is a way for management to manage transactions and business activities in a controlled manner to protect assets, produce reliable information, comply with government regulations, and generate effectiveness and efficiency of operations (Tatiana \&Umar, 2018). According to the Committee of Sponsoring Organizations of The Treadway Commission - COSO (2013), the internal control component consists of: (1) control environment, (2) risk assessment, (3) control activities, (4) information and communication, (5) ) monitoring.

Organizational commitment according to Allen and Meyer (1990) is about the conditions under which a company is committed to working with dedication, working for the need to provide more personnel and responsibilities for welfare and for supporting organizational needs. There are three components oforganizational commitmentincludingaffective commitment, normative commitment and continuance commitment.

\subsection{Effect of budgetary participation on managerial performance}

Employee participation in budgeting and the role of the budget as a performance measurement tool managerial has a close connection. According to Shields (1998), the staff is expected better in providinginformation for designing budget-based performance that is more efficient, so participation is generally seen as a managerial approach that can improve employee performance and organization.

As in the previous discussion, the budget compiled is not only determined by superiors only but also bysubordinates to give opinions and express information related towork as a contribution in determining the amount of the budget. As researchat the Malaysian Ministry of Defense (MINDEF) (see Yahya et al, 2008) shows, most of the respondents ccomingfrom middle and lower-level managers of civil and military departments indicated that a participatory relationship of the budget on managerial performance is positive and significant.

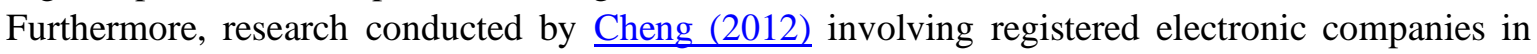
Taiwan as samples and 250 managers from these companies as respondentsindicates that budget participation and management accounting system have a positive and significant effect on managerial performance. Therefore, this research is intended to reexamine the effect of participation in the preparation budget for managerial performance in the state-owned plantation sector.

$\mathbf{H}_{1}$ : Participation in budgeting positively influences managerial performance.

\subsection{Effect of budgetary participation on managerial performance through internal control}

In preparing a budget, management requires calculations and deep considerations using resources and other factors outside the company. An internal control system plays a role in preventing things that can harm the company. According to Uleng et al. (2019), budgetary participation is one way to create a good management control system to achieve organizational goals.

Internal control activities are policies and procedures that help to convince that the actions are taken to examine the performance in the achievement of company objectives, namely in the form maximum performance. Internal control must be carried out efficiently and effectively because if it has been implemented properly, the company will be more able toimprove performance $(\underline{\mathrm{COSO}}$ $\underline{2013}$ ).

Internal control is an integral process with all stages of preparation and budget report. With supervision at every stage of budget management, then It is expected that the budget management process, especially in the budget preparation process, will enlarge its effect on managerial performance (Primadana et al., 2014).

Shields (1998) argues that budgetary participation increases employees' confidence, taste control and involvement in the organization, which leads to acceptance and commitment to budget decisions and lead to improved performance.

The results of research conducted by Gachoka et al. (2018) involving108 registered churches in the NCKK Church Council and EAK State of Kenya as a sample, shows that control internal gave positive intervening influences on the relationship between budgeting process and performance. Based on the explanation above, this study is intended to reexamine whether control internal will act as an 
intervening variable that influences the relationship between participation budgeting and managerial performance.

$\mathbf{H}_{2}$ : Participation in budgeting positively influences managerial performance through internal control as an intervening variable.

\subsection{Effect of budgetary participation on managerial performance through organizational commitment}

According to Setyawan and Rohman (2013), employees involved in the budget preparation process are expected to have a better commitment to the organization and feel like an important part of the organization. So, they will give their loyalty, or their best commitment and performance to achieve the company's goals.

High organizational commitment is needed in an organization. High commitment will affect professional work situations to achieve performance goals. Organizational commitment includes 3 attitudes, namely: (1) a sense of identification with organizational goals, (2) a sense of involvement with organizational tasks and (3) a sense of loyalty to the organization (Anola, 2011 in Apriyansyah et al., 2014).

Research by Nouri and Parker (1998), involving a sample of multinational companies in the field of chemical production in the United States with 203 respondents, namely managers and supervisors responsible for the budget, indicates that budgetary participation influenced performance work indirectly or intervened through budget sufficiency and commitment organization.

Furthermore, Haryanti and Othman's research (2012) with the Ministry of Home Affairs as a sample implementing new public management shows that budgetary participation had a positive effect on organizational commitment. In addition, intervening variables of organizational commitment have an important role in mediating the relationship between budgetary participation and managerial performance.

Using descriptions of organizational commitment that focuses on affective commitment, this study intends to re-examine whether organizational commitment (affective) will act as an intervening variable that affects the relationship between budgeting participation and performance managerial.

$\mathbf{H}_{3}$ : Participation in budgeting has a positive effect on managerial performance through organizational commitment as an intervening variable.

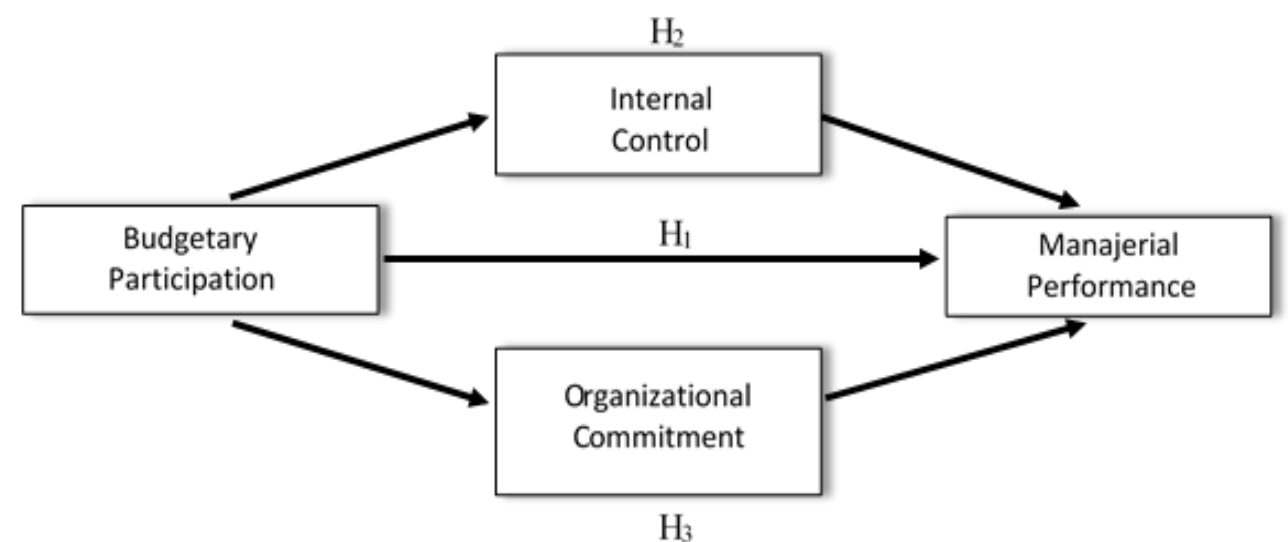

Figure 1. Research framework of the study

\section{Research methods}

\subsection{Data Collection}

This study used apurposive sampling method. There were 100 respondents who were top management and staff involved in the process budgeting at PTPN VII in the Lampung, South Sumatra and Bengkulu regions. Data collection was conducted by using a survey (questionnaire). The questionnaires were distributed in two ways: direct survey (distributed directly to the respondents) and mail survey (distributed via e-mail).

\subsection{Variables measurement}

This study used three types of variables, namely independent variable, intervening variables, and dependent variable. The variables include budget participation as the independent variable, internal 
control and organizational commitment as the intervening variables and managerial performance as the dependent variable.

\subsubsection{Budgeting Participation}

Measured by an instrument developed by Milani (1975) in Sumarno (2005), this study aims to measure participation and influence respondents in the budgeting process. Each respondent was asked to answer 5 items of thequestionnaire that measured their involvement in preparing for the budget by choosing a scale of 1 up to 7 showing the level of agreement and disagreement.

\subsubsection{Internal Control}

Following five elements of COSO control (2013) which includes control environment, risk assessment, control activities, information and communication, as well as monitoring, this instrument wasused by the Financial and Development Supervisory Agency (BPKP) of the Republic of Indonesia to examine the implementation of internal control systems in BUMN / BUMD / BUL. Each respondent was asked to answer 10 questions by choosing a scale of 1 to 7 showing the level of agreement and disagreement.

\subsubsection{Organizational Commitment}

Measured by the instrument developed by Mowday (1979) in Sumarno (2005), Each respondent was asked to answer 9 questions to examine an organizational commitment as an intervening factor which influences the relationship between drafting participation budget and managerial performance by choosing a scale of 1 to 7 showing the level of agreement and disagreement.

\subsubsection{Managerial Performance}

Measured by a self rating instrument developed by Mahoney et al. (1963) in Sumarno (2005) including eight dimensions, namely planning, investigation, coordination, evaluation, supervision, staffing, negotiation and representation, the respondents were asked to answer 8 questions to measure their own performance by choosing a scale of 1 to 7 showing the level of agreement and disagreement.

\subsection{Method of Analysis}

The method of analysis used in this study is the path analysis method (Path Analysis) by relying on SEM PLS with SmartPLS 3.2 software to assess the model measurement and structural models of research. SEM analysis of PLS includes measurements of the outer model (test model indicator, validity test and reliability test, measurement of inner model (coefficient of determinantion) or R2) and hypothesis testing.

Path coefficient includes the value of the path coefficient or the magnitude of the relationship or the influence of the construct latent. This test was done to ensure that the relationship between constructs is strong or good indicating both direct and indirect influences (intervening).

\section{Result and discussion}

Of the 100 questionnaires distributed, there were 100 returned questionnaires. Furthermore, valid questionnaires were processed and analyzed. All returned questionnaires were valid questionnaires so that the response rate was $100 \%$. Table 1 illustrates the number of questionnaires received.

Table 1. Questionnaires Data

\begin{tabular}{lcc}
\hline \multicolumn{1}{c}{ Description } & Quantity & Percentage \\
\hline Total of distributed questionnaires & 100 & $100 \%$ \\
Total of unreturned questionnaires & - & - \\
Total of returned questionnaires & 100 & $100 \%$ \\
Total of uncompleted questionnaires & - & - \\
Total of valid questionnaires & 100 & $100 \%$ \\
\hline
\end{tabular}

The results of the recapitulation of the questionnaire data generated the characteristics of respondents based on gender, last education, position, length of occupation, and experience in preparing the budget or RKAP which can be seen in table 2 .

Table 2. Respondents Characteristics 


\begin{tabular}{lcc}
\hline \multicolumn{1}{c}{ Decsription } & Quantity & Percentage \\
\hline Total Respondents & 100 & $100 \%$ \\
Gender & & \\
$\quad$ Male & 84 & $84 \%$ \\
$\quad$ Female & 16 & $16 \%$ \\
Latest Education & & \\
undergraduate & 88 & $88 \%$ \\
Post graduate (masters) & 12 & $12 \%$ \\
$\quad$ Etc & - & - \\
Current Position & & \\
$\quad$ Section Chief/ Manager & 15 & $15 \%$ \\
$\quad$ Directors of Subsidiaries & 4 & $4 \%$ \\
$\quad$ Head of Subdivision / Head Assistant & 31 & $31 \%$ \\
$\quad$ Head of Representative Office & 2 & $2 \%$ \\
$\quad$ Staff / Assistant & 48 & $48 \%$ \\
Length of Occupation & & $13 \%$ \\
$\quad$ Years & 13 & $29 \%$ \\
$\quad 2-5 \quad$ Years & 29 & $30 \%$ \\
$\quad 6-10$ Years & 30 & $28 \%$ \\
$>10 \quad$ Years & 28 & $14 \%$ \\
Experince in preparing budget & & $35 \%$ \\
$<5 \quad$ Years & 14 & $51 \%$ \\
$\quad$ 5-10 Years & 35 & 51 \\
\hline $10 \quad$ Years & & \\
\hline
\end{tabular}

\subsection{Descriptive statictics}

Table 3 shows that the number of respondents $(\mathrm{N})$ in this study was 100 people. Judgments given by respondents to each variable by descriptive statistics can be seen from the minimum value, maximum value, mode value, and standard deviation.

Table 3. Descriptive Statistics of Respondents

\begin{tabular}{|c|c|c|c|c|c|c|}
\hline Construct & Item & $\mathbf{N}$ & Min & Max & Std.Dev & Modus \\
\hline \multirow{5}{*}{ Budgeting Participation } & BP1 & 100 & 1 & 7 & 1,169 & 6 \\
\hline & BP2 & 100 & 1 & 7 & 1,542 & 5 \\
\hline & BP3 & 100 & 1 & 7 & 1,169 & 6 \\
\hline & BP4 & 100 & 1 & 7 & 1,136 & 6 \\
\hline & PA5 & 100 & 1 & 7 & 1,376 & 6 \\
\hline Average & & 100 & 1 & 7 & 1,278 & 6 \\
\hline \multirow{10}{*}{ Internal Control } & $\mathrm{IC} 1$ & 100 & 2 & 7 & 1,143 & 6 \\
\hline & $\mathrm{IC} 2$ & 100 & 2 & 7 & 1,062 & 6 \\
\hline & IC3 & 100 & 3 & 7 & 0,957 & 6 \\
\hline & $\mathrm{IC} 4$ & 100 & 1 & 7 & 1,176 & 6 \\
\hline & IC5 & 100 & 2 & 7 & 0,964 & 6 \\
\hline & IC6 & 100 & 3 & 7 & 0,777 & 6 \\
\hline & IC7 & 100 & 3 & 7 & 1,065 & 6 \\
\hline & IC8 & 100 & 1 & 7 & 1,132 & 6 \\
\hline & IC9 & 100 & 2 & 7 & 0,907 & 6 \\
\hline & IC10 & 100 & 2 & 7 & 1,019 & 6 \\
\hline Average & & 100 & 2 & 7 & $\mathbf{1 , 0 2 0}$ & 6 \\
\hline \multirow{9}{*}{ Organizational Commitment } & OC1 & 100 & 4 & 7 & 0,746 & 7 \\
\hline & $\mathrm{OC} 2$ & 100 & 2 & 7 & 1,044 & 6 \\
\hline & OC3 & 100 & 3 & 7 & 0,765 & 6 \\
\hline & OC4 & 100 & 3 & 7 & 0,840 & 6 \\
\hline & OC5 & 100 & 3 & 7 & 0,895 & 6 \\
\hline & OC6 & 100 & 2 & 7 & 0,998 & 6 \\
\hline & OC7 & 100 & 3 & 7 & 0,720 & 7 \\
\hline & OC8 & 100 & 2 & 7 & 0,961 & 6 \\
\hline & OC9 & 100 & 2 & 7 & 0,905 & 6 \\
\hline
\end{tabular}




\begin{tabular}{|c|c|c|c|c|c|c|}
\hline & & 100 & 3 & 7 & 0,875 & 6 \\
\hline \multirow{8}{*}{ Managerial Performance } & MP1 & 100 & 1 & 7 & 1,312 & 6 \\
\hline & MP2 & 100 & 1 & 7 & 1,087 & 6 \\
\hline & MP3 & 100 & 2 & 7 & 0,916 & 6 \\
\hline & MP4 & 100 & 3 & 7 & 0,986 & 6 \\
\hline & MP5 & 100 & 3 & 7 & 0,941 & 6 \\
\hline & MP6 & 100 & 1 & 7 & 1,218 & 6 \\
\hline & MP7 & 100 & 1 & 7 & 1,486 & 6 \\
\hline & MP8 & 100 & 1 & 7 & 1,421 & 6 \\
\hline \multicolumn{2}{|c|}{ Average } & 100 & 2 & 7 & 1,171 & 6 \\
\hline
\end{tabular}

\subsection{Test indicator model}

To find out whether each indicator was reliable with its latent variables, it was necessary to test the model indicators. Based on the results of data processing, it can be seen that all indicators had a loading factor value $>0.6$, which means all indicators werevalid indicators to measure the construct.

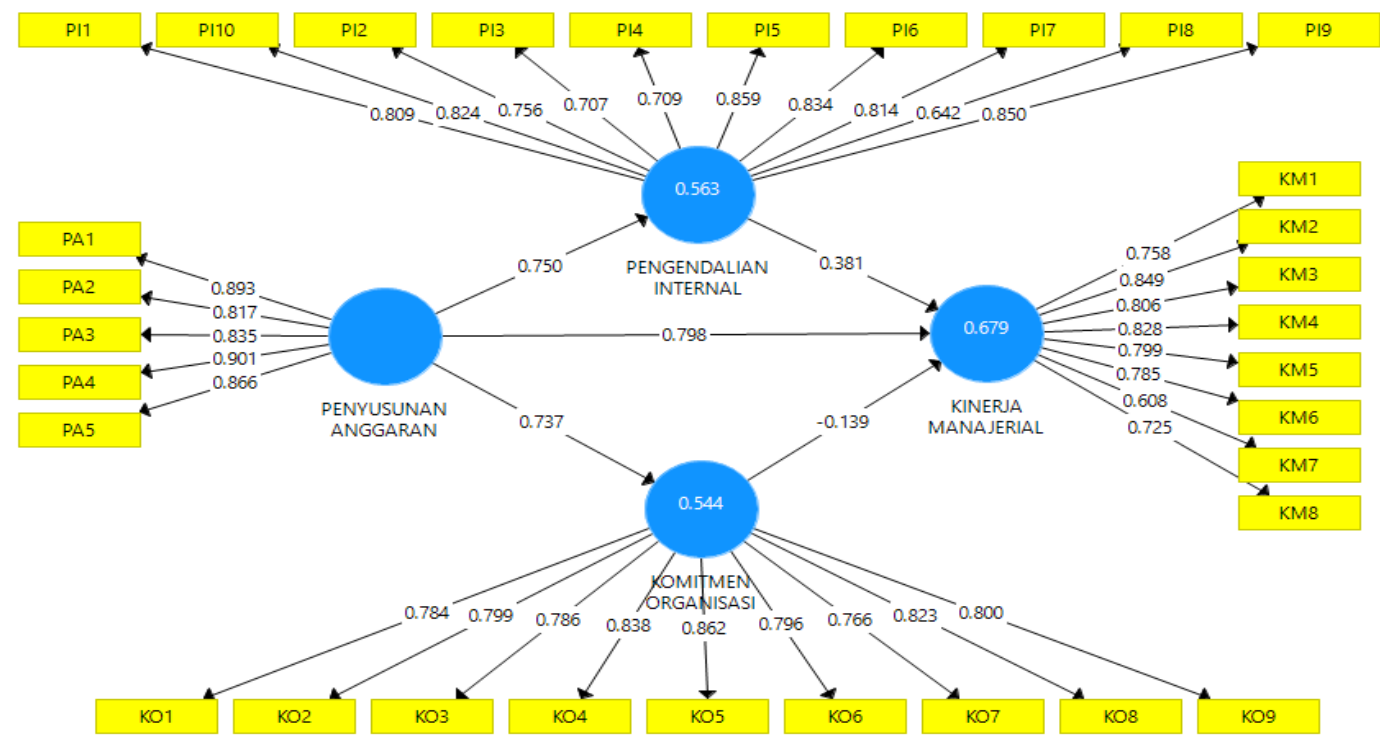

Figure 2. Loading Factor Value

\subsection{Test Convergent Validity}

The results of the analysis output presented in Table 4 show that all four latent variables or constructs had a value of AVE> 0.5 so that the convergent validity size wasgood or the measurement model met the validity criteria. The better convergent validity value was indicated by the higher correlation between the indicators composing a construct.

Table 4. Convergent Validity Value (AVE)

\begin{tabular}{lc}
\hline \multicolumn{1}{c}{ Construct } & $\begin{array}{c}\text { Average Variance Extracted } \\
\text { (AVE) }\end{array}$ \\
\hline Budgeting Participation & 0,7449 \\
Internal Control & 0,6140 \\
Organizational Commitment & 0,6505 \\
Managerial Performance & 0,5977 \\
\hline
\end{tabular}

\subsection{Test Discriminant Validity}

As seen in table 5, the cross loading value indicates a good disriminate validity because the correlation value of the indicator to the construct washigher than the correlation value of the indicator with other constructs. As illustrated in table 5, the indicators of budget participation in BP4 had a higher loading factor value (0.9013) than the loading factor with other constructs of internal control (0.7110), organizational commitment (0.6980) and managerial performance (0.7124). 
Table 5. Test Discriminant Validity

\begin{tabular}{ccccc}
\hline Budgetary & $\begin{array}{c}\text { Internal } \\
\text { Participation }\end{array}$ & $\begin{array}{c}\text { Organizational } \\
\text { Commitment }\end{array}$ & $\begin{array}{c}\text { Managerial } \\
\text { Performance }\end{array}$ \\
\hline BP1 & 0,8934 & 0,6438 & 0,6901 & 0,6151 \\
BP2 & 0,8168 & 0,5842 & 0,5251 & 0,7013 \\
BP3 & 0,8346 & 0,7029 & 0,6967 & 0,6601 \\
BP4 & 0,9013 & 0,7110 & 0,6980 & 0,7124 \\
BP5 & 0,8663 & 0,5834 & 0,5549 & 0,7563 \\
IC1 & 0,7864 & 0,8093 & 0,7215 & 0,7291 \\
IC2 & 0,5485 & 0,7563 & 0,6646 & 0,4891 \\
IC3 & 0,4165 & 0,7071 & 0,5444 & 0,4019 \\
IC4 & 0,4967 & 0,7095 & 0,5388 & 0,5917 \\
IC5 & 0,5934 & 0,8591 & 0,7262 & 0,5438 \\
IC6 & 0,6244 & 0,8340 & 0,6611 & 0,5769 \\
IC7 & 0,6579 & 0,8144 & 0,7301 & 0,5446 \\
IC8 & 0,4148 & 0,6423 & 0,5492 & 0,4684 \\
IC9 & 0,5817 & 0,8496 & 0,6674 & 0,5854 \\
IC10 & 0,6252 & 0,8239 & 0,6673 & 0,6562 \\
OC1 & 0,5385 & 0,7100 & 0,7843 & 0,4536 \\
OC2 & 0,5764 & 0,5727 & 0,7993 & 0,4083 \\
OC3 & 0,5209 & 0,6478 & 0,7862 & 0,4333 \\
OC4 & 0,5023 & 0,7012 & 0,8375 & 0,5016 \\
OC5 & 0,6663 & 0,6790 & 0,8623 & 0,5579 \\
OC6 & 0,6463 & 0,6123 & 0,7956 & 0,4920 \\
OC7 & 0,5503 & 0,6956 & 0,7664 & 0,5222 \\
OC8 & 0,6427 & 0,6795 & 0,8228 & 0,5483 \\
OC9 & 0,6609 & 0,7308 & 0,7999 & 0,6137 \\
MP1 & 0,6688 & 0,4148 & 0,3896 & 0,7576 \\
MP2 & 0,7409 & 0,6110 & 0,5859 & 0,8492 \\
MP3 & 0,6425 & 0,7107 & 0,5749 & 0,8065 \\
MP4 & 0,6642 & 0,6775 & 0,5486 & 0,8282 \\
MP5 & 0,6461 & 0,7120 & 0,5894 & 0,7989 \\
MP6 & 0,5927 & 0,5267 & 0,4367 & 0,7848 \\
MP7 & 0,4109 & 0,3055 & 0,3140 & 0,6084 \\
MP8 & 0,4823 & 0,3844 & 0,3611 & 0,7253 \\
\hline
\end{tabular}

\subsection{Test Composite Reliability and Cronbach's Alpha}

As seen In table 6, the four constructs had a composite reliability value> 0.7 or the established indicators had been able to measure each construct well or the measurement model had been reliable. Furthermore, the Cronbach's alpha test of the four constructs also shows a value of $>0.7$ or it can be concluded that all constructs had good reliability.

Table 6. Composite Reliability and Cronbach's Alpha Value

\begin{tabular}{lcc}
\hline \multicolumn{1}{c}{ Construct } & Composite Reliability & Cronbach's Alpha \\
\hline Budgeting Participation & 0,9358 & 0,9036 \\
Internal Control & 0,9404 & 0,9328 \\
Organizational Commitment & 0,9436 & 0,9293 \\
Managerial Performance & 0,9218 & 0,9140 \\
\hline
\end{tabular}

\subsection{Inner Model Measurement}

Chin (1998) divides the R2 value of 0.67; 0.33 and 0.19 into the good, moderate and weak model categories. The results of the R2 test analysis output can be seen in table 7. Internal control had a value of R-Square $(\mathrm{R} 2)=0.5632$, organizational commitment had a value of R-Square $(\mathrm{R} 2)=0.5436$, managerial performance had a value of $\mathrm{R}-$ Square $(\mathrm{R} 2)=0.6789$. In other words, it shows that this research had a moderate and good inner model.

Table 7. $\mathrm{R}^{2}$ Test Value

\begin{tabular}{lc}
\hline \multicolumn{1}{c}{ Construct } & Nilai $\mathbf{R}^{2}$ \\
\hline Internal Control & 0,5632 \\
Organizational Commitment & 0,5436
\end{tabular}




\subsection{Test Hypothesis}

The results of the t-statistic value obtained through the bootstrapping process are based on a sample of 100 employees of PT Perkebunan Nusantara VII in the areas of Lampung, South Sumatra and Bengkulu. The proposed hypothesis is accepted and significant if t-statistic $>1,96$ at a significance level of $5 \%$ and $\mathrm{p}$-value $<0.05$. As seen intable 8 , the organizational commitment proxy had a Tstatistic value of $1.2867<1.96$ and $p$-value of $1.2867>0.05$ or not significant. This shows that organizational commitment did not affect managerial performance.

Table 8. T-Statistic Test Value

\begin{tabular}{lcccccc}
\hline & $\begin{array}{c}\text { Original } \\
\text { Sample } \\
(\mathbf{O})\end{array}$ & $\begin{array}{c}\text { Sample } \\
\text { Mean } \\
(\mathbf{M})\end{array}$ & $\begin{array}{c}\text { Standard } \\
\text { Deviation } \\
\text { (STDEV) }\end{array}$ & $\begin{array}{c}\text { T Statistics } \\
(\mid \mathbf{O} / \text { STER })\end{array}$ & P Values & Significance \\
\hline $\begin{array}{l}\text { Budgetary } \\
\text { Participation } \rightarrow\end{array}$ & 0,7980 & 0,6316 & 0,0926 & 6,6312 & 0,0000 & Significance \\
$\begin{array}{l}\text { Managerial } \\
\text { Performance }\end{array}$ & & & & & & \\
$\begin{array}{l}\text { Budgetary } \\
\text { Participation } \rightarrow\end{array}$ & 0,7504 & 0,7580 & 0,0608 & 12,3363 & 0,0000 & Significance \\
$\begin{array}{l}\text { Internal Control } \\
\text { Budgetary }\end{array}$ & & & & & & \\
$\begin{array}{l}\text { Participation } \rightarrow \\
\text { Organizational } \\
\text { Commitment }\end{array}$ & 0,7373 & 0,7367 & 0,0565 & 13,0493 & 0,0000 & Significance \\
$\begin{array}{l}\text { Internal Control } \\
\rightarrow\end{array}$ & & & & & & \\
$\begin{array}{l}\text { Managerial } \\
\text { Performance }\end{array}$ & 0,3814 & 0,3617 & 0,1085 & 3,5157 & 0,0005 & Significance \\
$\begin{array}{l}\text { Organizational } \\
\text { Commitment } \rightarrow\end{array}$ & & & & & & \\
$\begin{array}{l}\text { Managerial } \\
\text { Performance }\end{array}$ & $-0,1395$ & $-0,1344$ & 0,1084 & 1,2867 & 0,1988 & Significance \\
\hline
\end{tabular}

Testing the direct and indirect effects (intervening) between the latent variables of each hypothesis was also obtained from the bootstrapping process, through the path coefficient of each hypothesis. Based on the results of bootstrapping in table 9, direct and indirect effects (intervening) between latent variables can be explained as follows:

Table 9. Path Coefficient Value

\begin{tabular}{lcccc}
\hline & Internal Control & $\begin{array}{c}\text { Organizational } \\
\text { Commitment }\end{array}$ & $\begin{array}{c}\text { Managerial } \\
\text { Performance }\end{array}$ & Total Effect \\
\hline $\begin{array}{l}\text { Budgeting } \\
\text { Participation }\end{array}$ & 0,7504 & 0,7373 & 0,7980 & \\
$\begin{array}{l}\text { Internal Control } \\
\begin{array}{l}\text { Organizational } \\
\text { Commitment }\end{array}\end{array}$ & & 0,3814 & 1,0842 \\
\hline
\end{tabular}

The loading factor of budgetary participation (BP) on managerial performance (MP) if through internal control (IC) became1.0842. The total effect was obtained by multiplying the indirect effect of $\mathrm{BP}$ on IC of 0.7504 with the indirect effect of IC on MP of 0.3814 , then the multiplication results were summed with the direct effect of BP on MP of 0.7980. Then, it can be seen that the indirect effect of $\mathrm{BP}$ on MP through ICwas greater than the direct effect of BP on MP. This indicates that internal control couldbe mediating (intervening) the relationship between budgeting participation and managerial performance. 
The loading factor of budget participation (BP) on managerial performance (MP) if through organizational commitment (OC) became 0.6951 . The total effect was obtained by multiplying the indirect effect of BP on OC by 0.7373 with the indirect effect of OC on MP by -0.1395 . Then the multiplication results were summed with the direct effect of BP on MP of 0.7980 . Then, it can be seen that the indirect effect of BP on MP through OCwas smaller than the direct effect of BP on MP. Besides that, there was no significant effect between OC and MP. This indicates that organizational commitment was not proven to be mediating (intervening) the relationship between budgeting participation and managerial performance.

\subsection{Discussion}

\subsubsection{Hypothesis test results $\mathrm{H}_{1}$}

Hypothesis testing $\mathrm{H}_{1}$ shows a positive influence with a t-statistic value of $6,142>1.96$ and a significance level $<0.05$ which is equal to 0.0000 . This shows the $\mathrm{H}_{1}$ hypothesis is accepted, it means that budgetary participation has a positive and significant effect on managerial performance. Thus, this research is supported by previous studies such as Arsalan et al. (2018), Setiadi and Yuyetta (2013), Cheng (2012), Eker (2007) as well Nouri and Parker (1998).

The performance of PTPN VII has been in an unhealthy condition since the last 10 years. Thisis the opposite to the accepted $\mathrm{H} 1$ hypothesis. This condition shows that there are other factors which affect the performance of PTPN VII, namely PTPN VII cash flow imbalance which is quite heavy due to falling prices of agro commodities in the global market, bad climate for agro commodities, and rejuvenation plants. (http://www.lampost.co). However, PTPN VII's growth chart continues to get better. This can be seen in the performance prognosis of PTPN VII in 2019 which shows a positive and better trend. For example, the revenue in 2019 reached Rp2,993 billion or better than the revenue in 2018 amounting to Rp2,875 billion, and the profit af estates in 2019 reached Rp475 billion or better compared to the revenue in 2018 amounting to Rp373 billion.

\subsubsection{Hypothesis test results $\mathrm{H}_{2}$}

Indirect effect between budgeting participation and internal control shows the $\mathrm{t}$-statistic value of $12.3363>1.96$ and a significance level $<0.05$ which is equal to 0.0000 or means that budgetary participation has a positive and significant effect on internal control.

The indirect effect between internal control and managerial performance shows the value of $t$ statistics of $3.5157>1.96$ and a significance level $<0.05$ which is equal to 0.0005 or mean s that internal control has a positive and significant effect on managerial performance.

The effect of budgetary participation on managerial performance if through internal control reaches 1.0842 or greater when compared to the value of the direct influence of participation budgeting for managerial performance of 0.7980 .

The discussion above shows that budgeting participation has a positive effect and significant to the internal control. And the internal control also has a positive and significant effect on managerial performance.

This means that internal control is proven as Intervening variables on the relationship between budgeting participation and managerial performance, which means the hypothesis $\mathrm{H} 2$ is accepted. This research supports previous studies such as Gachoka et al. (2018) who found a positive influence of internal control on the relationship between processes budgeting and performance.

This hypothesis is supported because the SPI Section of PTPN VII plays an active role in conducting self-assessment of internal control. The results of PTPN VII internal control assessment in 2018 are higher compared to the result in 2017 which is 82.51 or shows that the implementation of internal control at PTPN VII has been effective.

\subsubsection{Hypothesis testing results $\mathrm{H}_{3}$}

The indirect effect between budgeting participation and organizational commitment shows the tstatistic value of $13.0493>1.96$ and the significance level $<0.05$ which is equal to 0.0000 or means that budgetary participation has a positive and significant effect on commitment organization.

The indirect effect between commitment and managerial performance shows the $t$-statistic value of $1.2867>1.96$ and the significance level $<0.05$ which is equal to 0.1988 or means organizational commitment does not affect managerial performance.

The effect of budgetary participation on managerial performance if through organizational commitment becomes 0.6951 or smaller when compared to the value of the direct influence of participation budgeting for managerial performance of 0.7980 .

The description above shows that budgeting participation influences organizational commitment. However, organizational commitment does not affect managerial performance. This means that 
organizational commitment is not proven as an intervening variable relationship between budgetary participation and managerial performance, which means that the $\mathrm{H} 3$ hypothesis is rejected. The Findings in this study support those of the previous research such as Coenraad (2016) and Somers and Birnbaum (1998) which state that organizational commitment (affective and continuance) has no effect on performance. However, it is different form Setiadi and Yuyetta (2013), Haryanti and Othman (2012), Eker (2007), Supriyono (2004) and Naori and Parker's (1998) research which shows that managerial performance increases when there is an interaction between budgetary participation and organizational commitment.

\section{Conclusion}

Budgeting participation directly has a positive and significant effect on managerial performance. This contrasts with PTPN VII's unhealthy performance, so this condition shows that other factors affect PTPN VII's performance, namely a fairly heavy cash flow imbalance. However, PTPN VII's growth graph shows a positive trend. For example,the revenue in 2019 reached Rp2,993 Billion, which is, better than the revenue in 2018 reachingRp2,875 Billion. The profit of the plantation in 2019 reached Rp475 Billion, which is better than the revenue in 2018 reaching Rp373 Billion.

Participation in budgeting indirectly has a positive and significant effect on managerial performance through internal control as an intervening variable. The results of PTPN VII internal control assessment in 2018 were higher compared to the results in 2017, which was different by 82.51. This shows that the implementation of internal control at PTPN VII has been effective.

Budgeting participation does not affect managerial performance through organizational commitment as an intervening variable. It is suspected that respondents' perceptions of managerial performance and commitment are still not in line with the expectations, especially those related to assessments (key performance indicators) of employee's performance in return for implementing organizational commitment.

\section{Limitation and future study}

The research sample is still limited to employees in PTPN VII, while SOEs in the Plantation sector are incorporated in the Holding Company where PTPN III is the parent company, with subsidiaries consisting of PTPN I, II, IV, V, VI, VII, VIII, IX, X, XI, XII, XIII and XIV. This has an impact on the possibility of the employees' answers in which the research sample has not been able to represent the entire employees of the state-owned enterprise especially in plantation sector

The author only includes two intervening variables that mediate the relationship between budgetary participation and managerial performance, namely internal control and organizational commitment. Further researchneeds to consider other variables that can directly influence or mediate the relationship between budgeting participation and managerial performance, such as profitability, organizational culture or job satisfaction.

The author only applies the survey method through a questionnaire in measuring research variables. Hopefully, future studies can measure variables by adding interviews with respondents. The interview method is used to strengthen the results of research to obtain information directly on the limitations of the system that is already running. Additionally, the questionnaire was modified to provide deceptive statements so that respondents gave more information that was close to the actual conditions.

\section{References}

Allen, N. J. \& Meyer, J. P. (1990). The measurement and antecedents of affective, continuance and normative commitment. International Journal of Occupational Psychology.

Anwar, Chairil. (2018). Performa membaik, PTPN VII optimis segera lalui masa sulit. Lampung Post. Retrieved from http://www.lampost.co

Apriansyah, Ginanjar., Zirman \& Rusli. (2014). Pengaruh partisipasi anggaran, komitmen organisasi, kepuasan kerja, job-relevant information dan budaya organisasi terhadap kinerja manajerial pada perhotelan di Provinsi Riau. JOM FEKON Vol.1 No.2.

Arsalan, Syakieb., Mohd Saudi, M.H., Susiani, Rini., \& Adison, Acep. (2018). Effect of participative budgeting, organizational commitment and work motivation on managerial performance (survey of motor vehicle dealers in Bandung). International Journal of Engineering \& Technology, Vol. 7 /4.34, Page 240-244.

Aulad, Afdalul., Hidayati, Nur., \& Junaidi. (2018). Pengaruh partisipasi penyusunan anggaran terhadap kinerja aparat pemerintah daerah : Budaya organisasi dan komitmen organisasi 
sebagai variabel moderating (studi empiris pada SKPD Kota Malang). e-JRA Jurnal Riset Akuntansi Vol.7, FEB Universitas Islam Malang.

Brownell, P. (1982). Participation in the budgeting process : When it works and when it doesn't.Massachusetts Institute of Technology. Retrieved from https://dspace.mit.edu/bitstream/handle/1721.1/48829

Cheng, M.T. (2012). The joint effect of budgetary participation and broad-scope management accounting systems on management performance. Asian Review of Accounting Vol. 20 No. 3, 2012 pp. 184-197. Emerald Group Publishing Limited 1321-7348 DOI 10.1108/13217341211263256.

Coenraad, Dhea Perdana. (2016). Pengaruh kemampuan, motivasi dan komitmen terhadap kinerja pegawai. Jurnal Ekonomi, Bisnis dan Entrepreneurship Vol. 10, No. 1, Hal. 17-24, ISSN $2443-$ 2121.

Eker, Melek. (2007). The impact of budget participation on managerial performance via organizational commitment: A study on the top 500 frims in Turkey. Ankara Üniversitesi SBF Dergisi, Page 116-136.

Gachoka, Norman., Aduda, Josiah., Kaijage, Erasmus. \& Okiro, Kennedy. (2018). The intervening effect of internal controls on the relationship between budgeting process and performance of churches in Kenya. Journal of Finance and Investment Analysis, vol. 7, no. 2, 2018, 53-79 ISSN: 2241-0998 (print version), 2241-0996(online) Scienpress Ltd.

Haryanti, Ida M.N. \& Othman, R. (2012), Budgetary participation: How it affects performance and commitment. Accountancy Business and the Public Interest, Vol. 11, No. 2, Page 53-73.

Indarto, S.L., \& Ayu, S.D. (2011). Pengaruh partisipasi dalam penyusunan anggaran terhadap kinerja manajerial perusahaan melalui kecukupan anggaran, komitmen organisasi, komitmen tujuan anggaran, dan Job Relevant Information (JRI). SERI KAJIAN ILMIAH, Vol. 14, Fakultas Ekonomi, Unika Soegijapranata Semarang.

Lau, C.M. \& Tan, S.L.C. (2012). Budget targets as performance measures : The mediating role participation and procedural fairness. Advances in Management Accounting, Volume 20, pp. 151-185. Emerald Group Publishing Limited. ISSN: 1474-7871/ doi: 10.1108/ S1474-7871 (2012)0000020013

Nouri, H. \& Parker, R.J. (1998). The relationship between budget participation and job performance: the roles of budget adequacy and organizational commitment. Accounting, Organization and Society, Vol. 23, No 5/6, Page 467-483.

Poerwati, Tjahjaning. (2002). Pengaruh partisipasi terhadap kinerja manajerial: Budaya Organisasi dan Motivasi sebagai Variabel Moderating. Simposium Nasional Akuntansi V, Semarang 5-6 September 2002.

Primadana, G.H.M., Yuniarta, G.A. \& Adiputra, M.P. (2014). Pengaruh partisipasi dalam penyusunan anggaran, kejelasan sasaran anggaran dan struktur desentralisasi terhadap kinerja manajerial SKPD dengan Pengawan Internal Sebagai Variabel Pemoderasi (Studi Empiris Pada Pemerintah Kabupaten Badung). e-Journal S1 Ak Universitas Pendidikan Ganesha, Vol. 2, No. 1

Rosman, R.I., Shafie, N.A., Sanusi, Z.M., Johari, R.J., \& Omar, N. (2016). The effect of internal control systems and budgetary participation on the performance effectiveness of non-profit organizations: Evidence from Malaysia. Pertanika Journal, International Journal of Economics and Management 10 (S2), Page 523 - 539.

Somers, M. J., \& Birnbaum, Dee. (1998). Work-related commitment and job performance: It's also the nature of the performance that counts. Journal of Organizational Behavior, (19) : 621-634

Selvina, M., \& Yuliansyah, Y. (2015). Relationships between budgetary participationand organizational commitment:Mediated by reinforcement contingency.International Research Journal of Business Studies, 8(2), 69-80.

Setiadi, Hidayat \& Yuyetta E.N.A. (2013). Pengaruh partisipasi anggaran terhadap kinerja manajerial melalui komitmen organisasi dan budget emphasis sebagai variabel intervening. Diponegoro Journal of Accounting, Vol. 2, No. 4, Page. 3, ISSN : 2337-3806.

Setyawan, Ariyanto \& Rohman, Abdul. (2013). Pengaruh partisipasi anggaran terhadap kinerja manajerial dengan mediasi komitmen organisasi dan kecukupan anggaran. Diponegoro Journal of Accounting, Vol. 2, No. 3, Page. 1, ISSN : 2337-3806.

Shields, J.F., \& Shields., M.D. (1998). Antecedents of participative budgeting. Accounting, Organizations and Society, Vol. 23, No. 1, Page. 49-76, Elsevier Science Ud. All rights reserved. Printed in Great Britain 0361-3682/98 
Sumarno, J. (2015). Pengaruh komitmen organisasi dan gaya kepemimpinan terhadap hubungan antara partisipasi anggaran dan kinerja manajerial (Studi empiris pada kantor cabang perbankan Indonesia di Jakarta). Jurnal Bisnis Strategi, vol. 14, no. 2, pp. 197-210

Supriyono, R.A. (2004). Pengaruh variabel intervening kecukupan anggaran dan komitmen organisasi terhadap hubungan antara partisipasi penganggaran dan kinerja manajer di Indonesia. Jurnal Ekonomi dan Bisnis Indonesia Universitas Gajah Mada, Vol. 19, No. 3, Hal. 282-298

Tatiana, R.A.A., \& Umar, Haryono. (2018). pengaruh pengendalian internal dan audit internal terhadap kinerja penjualan perusahaan (studi pada PT B\&K Baja Utama). Jurnal Riset Perbankan Manajemen \& Akuntansi Vol.2, No.1, ISSN: 2541-6669.

The Committee of Sponsoring Organizations of The Treadway Commission (COSO). (2013). Internal Control - Integrated Framework. ISBN 978-1-93735-239-4.

Uleng, Nirwana \& Syamsudin. (2019). Pengaruh Sumber Daya Manusia, partisipasi anggaran, dan gaya kepemimpinan terhadap kualitas informasi laporan keuangan dan pengendalian internal sebagai variabel moderasi (studi kasus pada pemerintahan Kabupaten Takalar). Jurnal Bisnis, Manajemen dan Informatika, Vol. 16, No.1

Yahya, M.N., Nik Ahmad, N.N., \& Fatima, A.H. (2008). Budgetary participation and performance: some Malaysian evidence. International Journal of Public Sector Management Vol. 21 No. 6 , pp. 658-673. Emerald Group Publishing Limited 0951-3558 DOI $10.1108 / 09513550810896523$.

Yuliansyah, Y., \& and Khan, A. A. (2017). A revisit of the participative budgeting and employees' self-efficacy interrelationship - empirical evidence from Indonesia's public sector. International Review of Public Administration, 22(3), 213-230.

Yuliansyah, Y., Inapty, B. A., Dahlan, M., \& Agtia, I. O. (2018). Budgetary participation and its impact on individual performance. Tourism and Hospitality Management, 24(2), 325-340.

Yuliansyah, Y., Triwacananingrum, W., Mohd-Sanusi, Z., \& Said, J. (2019). Enhancing the task performance of bank employees: relevance of trust, self-efficacy, and budget participation. International Journal of Business Excellence, 17(4), 397-413. 